DOI: $10.12737 /$ article_5c1a320e647bd4.28590993

УДК 633.63.693:631.53

\author{
ВЛИЯНИЕ НИЗКОИНТЕНСИВНОГО КОГЕРЕНТНОГО ИЗЛУЧЕНИЯ НА СОХРАННОСТЬ \\ ПОСАДОЧНОГО МАТЕРИАЛА \\ доктор сельскохозяйственных наук О. А. Подвигина ${ }^{1}$ \\ кандидат технических наук И. И. Бартенев ${ }^{1}$ \\ кандидат сельскохозяйственных наук С. В. Сащенко ${ }^{2}$ \\ 1 - ФГБНУ «Всероссийский научно-исследовательский институт сахарной свеклы и сахара \\ имени А.Л. Мазлумова», пос. ВНИИСС, Российская Федерация \\ 2 - ООО «Бетагран Рамонь», пос. ВНИИСС, Российская Федерация
}

Представлены литературные данные о влиянии лазерной обработки посевного и посадочного материала сельскохозяйственных и древесных культур на устойчивость растений к патогенам - возбудителям болезней. Низкоинтенсивное когерентное излучение (НКИ) создает условия для усиления или торможения активности биохимических процессов, отвечающих за включение ростовых, иммунных и других систем в растениях. Проведенные исследования были направлены на повышение сохранности маточных корнеплодов сахарной свеклы посредством их обработки лазерным излучением. Источником низкоинтенсивного когерентного излучения служила установка ЛОС-25А с плотностью мощности 1.886 Вт. Экспозиция лазерной обработки составляла 15, 30 и 45 секунд. Обработке подвергались маточные корнеплоды сахарной свеклы гибрида РМС 73 перед закладкой их на длительное хранение. В результате исследований установлено, что основными возбудителями, паразитирующими на корнеплодах сахарной свеклы во время хранения, являются Botrytis cinerea и Fusarium solam. Поражение корнеплодов микроорганизмами зависит от степени травмирования их при механической уборке. Обработка корнеплодов лазером позволила снизить загнивание хвостовой части почти в 2 раза и процессы возобновления роста в период хранения, т. е. израстание корнеплодов, в 4 раза. Величина отрастающих листьев у обработанных лазером корнеплодов не превышала 3 см, на контрольном варианте листья достигали 5-10 см. Обламывание отрастающих листьев и центральной почки на корнеплодах ведет к снижению семенной продуктивности растений. Применение обработки маточных корнеплодов лазерным излучением при различных экспозициях позволило к весенней посадке сохранить 85-94 \% корнеплодов. Максимальный выход деловых корнеплодов маточной сахарной свеклы отмечен в варианте с обработкой НКИ при 30-секундной экспозиции. Разработан способ повышения сохранности маточных корнеплодов с использованием низкоинтенсивного когерентного излучения.

Ключевые слова: сахарная свекла, маточные корнеплоды, сохранность, лазерное облучение, фитопатогены.

\title{
EFFECT OF LOW-INTENSITY COHERENT RADIATION ON THE SURVAVAL OF PLANTING MATERIAL
}

DSc (Agriculture) O. A. Podvigina ${ }^{1}$

$\mathrm{PhD}$ (Engineering) I. I. Bartenev ${ }^{1}$

$\mathrm{PhD}$ (Agriculture) S. V. Sashchenko ${ }^{2}$

1 - Federal State Budgetary Scientific Institution «All-Russian Research Institute of Sugar Beet and Sugar named after A.L. Mazlumov», village VNIISS, Russian Federation

2 - LLC «Betagran Ramon», village VNIISS, Russian Federation

\begin{abstract}
The literature data on the effect of laser treatment of seed and planting material of agricultural and tree species on plant resistance to pathogens are presented. Coherent radiation of low-intensity (CRLI) creates conditions for enhancing or inhibiting the activity of biochemical processes responsible for the inclusion of growth, immune and other systems in plants. The studies have been aimed at improving the safety of mother root crops of sugar beet through their processing
\end{abstract}


by laser radiation. The LOS-25A installation with a power density of $1.886 \mathrm{~W}$ served as the source of coherent radiation of low-intensity. The exposure of laser processing was 15, 30 and 45 seconds. Processing was subjected to mother roots of sugar beet (hybrid PMC 73) before laying them for long-term storage. As a result of the research, it has been established that the main pathogens parasitizing on sugar beet root crops during storage are Botrytis cinerea and Fusarium solam. The defeat of root crops by microorganisms depends on the degree of injury to them during mechanical harvesting. Processing of root vegetables with a laser allowed reducing rotting of the root part almost 2 times and the processes of resumption of growth during storage, i.e. the growth of root crops - 4 times. The size of the growing leaves of the laser-treated root crops did not exceed $3 \mathrm{~cm}$, leaves reached $5-10 \mathrm{~cm}$ on the control variant. Breaking of growing leaves and central bud on the roots leads to a decrease in seed productivity of plants. The use of treatment of mother root crops with laser radiation at various exposures made it possible to save $85-94 \%$ of the root crops for spring planting. The maximum yield of root mother sugar beet was noted in the variant with CRLI treatment at a 30 second exposure. A method has been developed to improve safety of mother root crops using coherent radiation of low-intensity.

Keywords: sugar beet, mother root crops, safety, laser irradiation, phytopathogens.

Применение физических, химических и биотических дестабилизирующих факторов усиливает различные типы защитных реакций растений. Одним из таких методов воздействия на защитную систему растений является применение низкоинтенсивного когерентного излучения (НКИ), представляющего собой излучение оптической области спектра, обладающее большей статисти-ческой упорядоченностью (когерентностью), чем рассеянный солнечный свет, и интенсивностью, не вызывающей тепловой деструкции биоструктур $[3,9]$.

Проведенные различными исследователями эксперименты $[4,5]$ показали, что действие когерентного излучения носит опосредованный характер. Включение тех или иных систем (репарационных, ростовых, иммунных и т.д.) вызывается процессами биохимической регуляции, а НКИ лишь создает условия для изменения (усиления или торможения) их активности.

Среди разных стимулирующих эффектов лазерного излучения следует обратить особое внимание на повышение устойчивости растений к патогенам возбудителям болезней. Существует целый ряд научных публикаций, подтверждающих перспективность применения лазерной обработки для повышения иммунитета сельскохозяйственных и древеснокустарниковых пород. Так, после лазерной обработки семян зерновых и крупяных культур в Сумской области Украины в среднем за 7 лет поражение растений ячменя пыльной головней снизилось в 3,5 раза, в 15-20 раз уменьшилась гибель проростков ячменя, проса и гречихи от фузариоза. В несколько раз выросла устойчивость ячменя к твердой головне и корневым гнилям, пшеницы к пыльной головне, томатов к черному бактериозу [1]. Выявлено, что в Краснодарском крае на рисовых полях, засеянных активированными лазером семенами, не возникло очагов пирикуляриоза [8]. Отмечена более высокая устойчивость тепличных растений против вирус-ной, грибковой и нематодной инфекции $[7,10]$.

У древесных пород после лазерной обработки семян выход посадочного материала увеличился в среднем на $10-12 \%$ у хвойных растений, на $7 \%$ - у тополя в сравнении с контролем. Обработка лучами лазера вегетирующих растений рябины в возрасте 6 недель позволила обеззаразить их корневые шейки от гнили и тем самым предотвратить распространение болезни на весь посев [11].

На сахарной свекле были проведены исследования только по применению лазерного облучения семян с целью повышения их всхожести и содержания сахара в корнеплодах [6, 12].

Целью наших исследований явилось изучение влияния НКИ на сохранность маточных корнеплодов сахарной свеклы при длительном хранении.

Исследования проводились в ФГБНУ «ВНИИСС им. А.Л. Мазлумова». Объектом изуче-ния являлись корнеплоды гибрида сахарной свеклы РМС 73. Источником низкоинтенсивного когерентного излучения служила установка ЛОС-25А с плотностью мощности 1.886 Вт, любезно предоставленная А.В. Будовским из Всероссийского НИИ генетики и селекции плодовых растений (г. Мичуринск). Экспозиция лазер- 


\section{Генетика. Селекция. Биотехнологии}

ной обработки составляла 15,30 и 45 секунд. Маточные корнеплоды обрабатывались перед закладкой на хранение (рис. 1). Хранение их с октября по апрель проводилось в стационарном корнехранилище при температуре $2-3{ }^{\circ} \mathrm{C}$ и относительной влажности воздуха 85-90 \%. Микробиологические исследования проводились на базе лаборатории иммунитета ВНИИСС с использованием методов выделения, культивирования и хранения чистых культур микроорганизмов [2]. В процессе длительного хранения корнеплодов был проведен идентификационный анализ комплекса фитопатогенов, паразитирующих на корнеплодах сахарной свеклы. Установлено, что основными возбудителями являются Botrytis cinerea и Fusarium solani (рис. 2). Количество микроорганизмов и их видовой состав определялся лишь «питательной средой» (сахаристостью) материала.
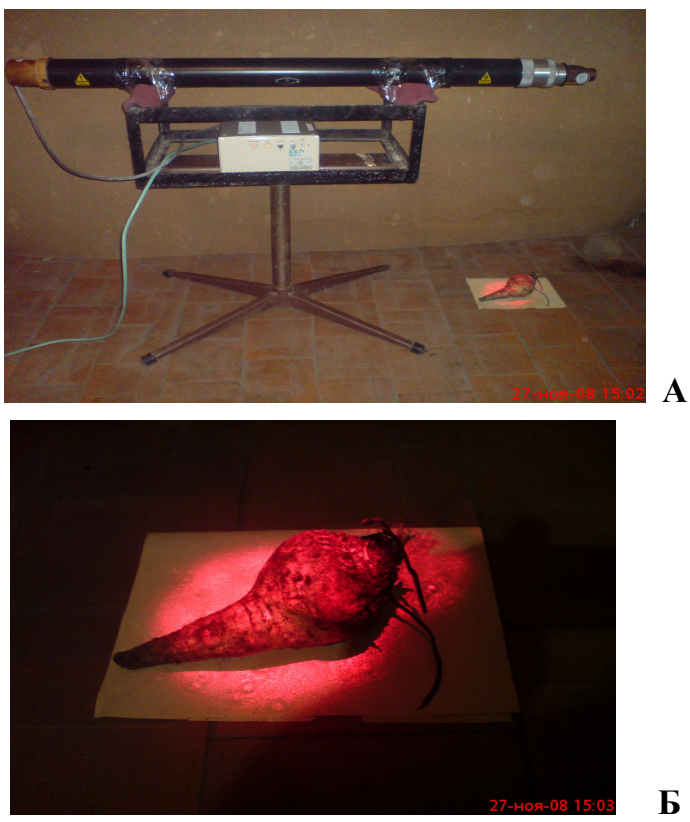

Рис. 1. Внешний вид лазерной установки (А), обработка корнеплода сахарной свеклы излучением (Б)

Основной причиной, снижающей устойчивость корнеплодов к фитопатогенным микроорганизмам и увеличивающей потери массы и сахара при хранении, является их механическое повреждение во время уборки, особенно обрыв хвостовой части.

Обработка маточных корнеплодов НКИ показала положительный результат. На обработанных лазером корнеплодах наблюдалось снижение их повреждения патогенной микрофлорой, особенно на раневых

Лесотехнический журнал 4/2018 поверхностях. Загнивание хвостовой (обломанной) части корнеплодов у обработанного лазером материала составляло в среднем $14,2 \%$ от общего количества, а на контрольном варианте данный показатель находился на уровне $26,8 \%$ (рис. 3 ).

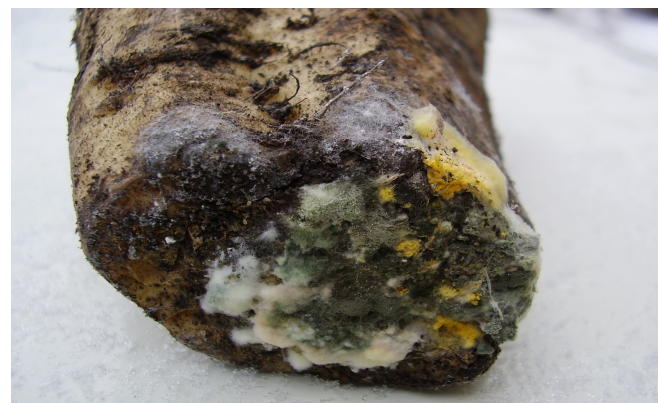

$\mathbf{A}$

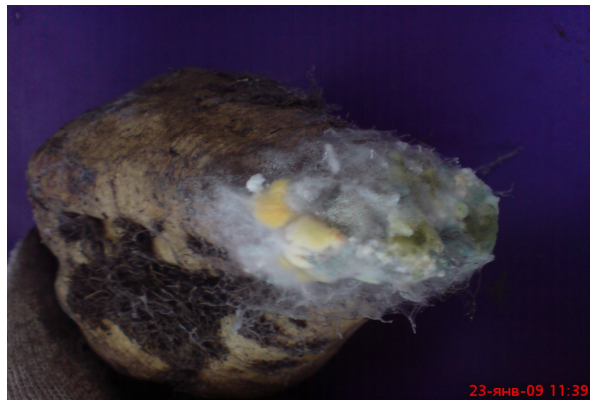

Б

Рис. 2. Внешний вид пораженных корнеплодов в период хранения

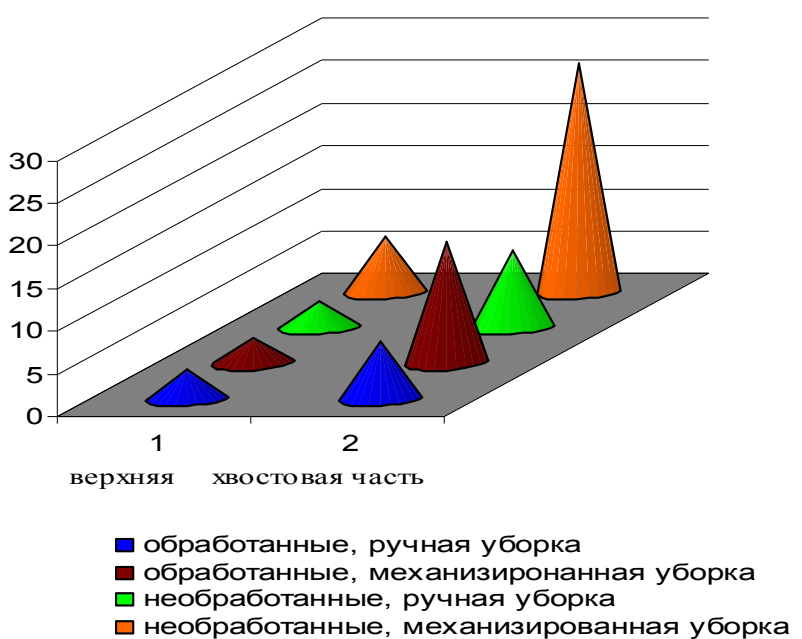

Рис. 3. Влияние НКИ на показатели сохранности корнеплодов в условиях хранилища при различных способах уборки

Снижение поражения патогенной микрофлорой можно объяснить снижением концентрации фенолов при лазерном облучении, вызванным их более активным включением в метаболизм растительных клеток. В 
данном случае за счет синтеза лигнина, являющегося защитным барьером для проникновения микроорганизмов.

Ещё одним положительным моментом обработки маточных корнеплодов лазерным излучением явилось значительное снижение процессов возобновления роста в период хранения, т. е. израстания корнеплодов. У обработанных лазером корнеплодов степень израстания колебалась в пределах 4,5-5,1%, у необработанных корнеплодов данный показатель достигал 22.0 \% (рис. 4).

Интенсивность израстания (длина про-ростков) у обработанных лазером корнеплодов не превышала 3 см, на контрольном варианте данный показатель достигал 5-10 см. Проростки более 3 см часто отламываются при дальнейших работах - затаривании, транспортировке, посадке. В результате этого повреждается центральная почка, обеспечивающая формирование центрального побега с большим количеством лучших семян. Это ведет к снижению семенной продуктивности растений сахарной свеклы.

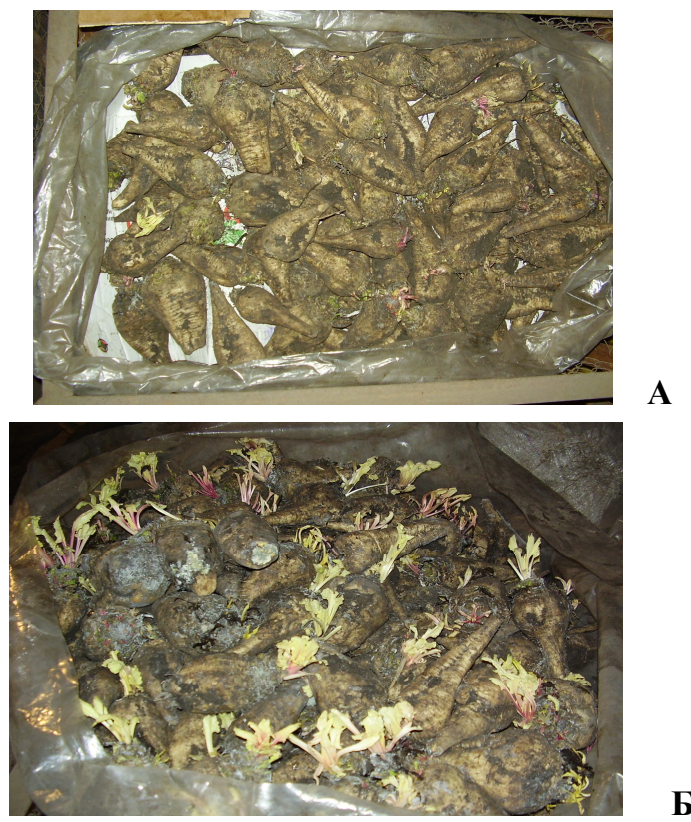

Рис. 4. Контейнер с материалом, обработанным НКИ (А), и контрольный вариант (Б)
Когерентное излучение расширяет спектр приспособительных реакций растительных организмов, увеличивает их жизнеспособность и функциональную активность. При лазерном облучении состояние окислительно-восстановительного потенциала клетки может смещаться как в прооксидантную, так и в антиоксидантную сторону. Это зависит от условий жизнедеятельности организма и состояния его внутренней среды. Лазерное излучение способствует созданию потенциальных возможностей усиления процессов, которые запускаются в соответствии с прохождением онтогенеза, гомеостатическими реакциями организма, действием эндогенных и экзогенных факторов [3]. Поэтому обработанные корнеплоды в период хранения не активизировали ростовые процессы, и степень их израстания находилась на незначительном уровне.

Применение обработки маточных корнеплодов лазерным излучением при различных экспозициях позволило к весенней посадке сохранить 85-94 \% корнеплодов. Максимальный выход деловых корнеплодов маточной сахарной свеклы отмечен в варианте с обработкой НКИ при 30-секунд-ной экспозиции. Применение НКИ с экспозициями 15 и 45 секунд позволило повысить выход деловых корнеплодов в сравнении с контролем (70\%), но максимального значения при этих параметрах получить не удалось.

Применение НКИ способствовало повышению сохранности маточных корнеплодов в период осенне-весеннего хранения за счет снижения поражения патогенной микрофлорой и активизации ростовых процессов (израстания корнеплодов). На основе проведенных исследований был разработан способ повышения сохранности маточных корнеплодов с использованием низкоинтенсивного когерентного излучения (лазера).

Полученные результаты исследований могут быть использованы при разработке специализированных линий для облучения посадочного материала различных культур при его хранении в производственных масштабах.

\section{Библиографический список}

1. Бельский, А. И. Влияние светолазерной обработки семян сельскохозяйственных культур на устойчивость растений к болезням [Текст] / А. И. Бельский // Борьба с сорняками, вредителями и болезнями в интенсивном земледелии. - Горки, 1987. - С. 67-73. 


\section{Генетика. Селекция. Биотехнологии}

2. Билай, В. И. Определение роста и биосинтетической активности грибов [Текст] / В. И. Билай // Методы экспериментальной микологии : справ. ; под ред. В. И. Билай. - Киев : Наукова думка, 1982. - С. 5-17.

3. Будовский, А. В. О способности клеток различать когерентность оптического излучения [Текст] / А. В. Будовский // Квантовая электроника. - 2005. - Т. 35. - № 4. - С. 369-374.

4. Быховский, В. К. О передаче когерентности в электронную оболочку биологических макромолекул и их комплексов [Текст] / В. К. Быховский // Биофизика. - 1973. - Т. 18. - Вып. 1. - С. 184-186.

5. Гамалея, Н. Ф. Новые данные по фоточувствительности животной клетки и механизму лазерной биостимуляции [Текст] / Н. Ф. Гамалея, Е. Д. Шишко, Ю. В. Яниш // Доклады АН СССР. - 1983. - С. $224-227$.

6. Гниломедов, В. П. О высеве замоченных семян сахарной свеклы [Текст] / В. П. Гниломедов, Н. В. Калугина // Сахарная свекла. - 1984. - № 2. - С. 15-18.

7. Грознев, В. П. Предпосевное облучение как фактор повышения устойчивости томатов против вирусной, грибковой и нематодной инфекции [Текст] / В. П. Грознев, Ш. А. Якубов // Тезисы 6-й Всесоюзной конференции по фотоэнергетике растений. - Львов, 1980. - С. 124.

8. Журба, П. С. Авторское свидетельство на изобретение № 1827744 «Способ борьбы с болезнями риса» [Текст] / П. С. Журба, С. А. Дякунчак, М. Б. Попова. - М., 19.06.1991.

9. Канталинский, В. С. Изменение общей резистентности и повышение устойчивости гвоздики ремонтантной к заболеванию ржавчиной и фузариозом при лазерном воздействии [Текст] / В. С. Канталинский, Н. А. Орлова // Проблемы энергофикации народного хозяйства Казахстана. - Алма-Ата, 1989. - С. 56-57.

10. Лысикова, Г. В. Предпосевное облучение семян огурцов лазером в условиях защищенного грунта [Текст] / Г. В. Лысикова // Использование биофизических методов в генетико-селекционном эксперименте : тез. докл. Всесоюз. конференции. - Кишинев, 1977. - С. 59.

11. Максименко, А. П. Использование лазера в лесном хозяйстве [Текст] / А. П. Максименко, В. А. Герш, Е. Н. Гвоздык // Лазерные технологии в сельском хозяйстве. Тематический сборник. - М. : Техносфера, 2008. C. 124-129.

12. Плохих, В. Б. Лазер в селекции и семеноводстве [Текст] / В. Б. Плохих, Л. Б. Мацуцина // Сахарная свекла. - 1985. - С. 29-31.

\section{References}

1. Belsky A. I. Vliyaniye svetolazernoy obrabotki semyan sel'skokhozyaystvennykh kul'tur na ustoychivost' rasteniy $k$ boleznyam [Effect of light laser treatment of seeds of agricultural crops on plant resistance to disease] Bor'ba s sornjakami, vrediteljami i boleznjami v intensivnom zemledelii [Fight against weeds, pests and diseases in intensive agriculture] Gorki, 1987, pp. 67-73. (in Russian)

2. Bilay V. I. Opredeleniye rosta i biosinteticheskoy aktivnosti gribov [Determination of growth and biosynthetic activity of fungi] Kiev, 1982, pp. 5-17. (in Russian)

3. Budovsky A. V. O sposobnosti kletok razlichat' kogerentnost' opticheskogo izlucheniya [About the ability of cells to distinguish the coherence of optical radiation] Kvantovaja jelektronika [Quantum Electronics], 2005, Vol. 35, no 4, pp. 369-374. (in Russian)

4. Bykhovsky V. K. O peredache kogerentnosti v elektronnuyu obolochku biologicheskikh makromolekul i ikh kompleksov [On the transfer of coherence into the electron shell of biological macromolecules and their complexes] Biofizika [Biophysics], 1973. Vol.18, Issue 1, pp. 184-186. (in Russian)

5. Gamaleya N. F., Shishko E. D., Yanish Yu. V. Novyye dannyye po fotochuvstvitel'nosti zhivotnoy kletki $i$ mekhanizmu lazernoy biostimulyatsii [New data on the photosensitivity of an animal cell and the mechanism of laser biostimulation] Doklady AN SSSR [Reports of the Academy of Sciences of the USSR], 1983, pp. 224-227. (in Russian)

6. Gnilomedov V. P., Kalugina N. V. O vyseve zamochennykh semyan sakharnoy svekly [About seeding soaked sugar beet seeds] Saharnaja svekla [Sugar beet], 1984, no 2, pp. 15-18. (in Russian)

7. Groznev V. P., Yakubov Sh. A. Predposevnoye oblucheniye kak faktor povysheniya ustoychivosti tomatov 


\section{Генетика. Селекция. Биотехнологии}

protiv virusnoy, gribkovoy i nematodnoy infektsii [Pre-sowing irradiation as a factor in increasing the resistance of tomatoes against viral, fungal and nematode infections] Tezisy 6-j Vsesojuznoj konfe-rencii po fotojenergetike rastenij [Abstracts of the 6th All-Union Conference on Plant Photo-Energy]. Lviv, 1980, pp. 124 (in Russian)

8. Zhurba P. S., Dakunchak S. A., Popova M. B. Avtorskoye svidetel'stvo na izobreteniye №1827744 «Sposob bor'by s boleznyami risa» [Author's certificate on the invention №1827744 "The way to combat diseases of rice"] Moscow, 1991. (in Russian)

9. Kantalinsky V. S., Orlova N. A. Izmeneniye obshchey rezistentnosti i povysheniye ustoychivosti gvozdiki remontantnoy $k$ zabolevaniyu rzhavchinoy i fuzariozom pri lazernom vozdeystvii [Change in general resistance and increase in the resistance of the clove of the remontant to the disease of rust and fusarium with laser exposure] Problemy jenergofikacii narodnogo hozjajstva Kazahstana [Problems of the National Economy of Kazakhstan] Alma-Ata, 1989, pp. 56-57. (in Russian)

10. Lysikova G. V. Predposevnoye oblucheniye semyan ogurtsov lazerom v usloviyakh zashchishchennogo grunta [Pre-sowing irradiation of cucumber seeds with a laser in protected ground] Ispol'zovanie biofizicheskih metodov $v$ genetiko-selekcionnom jeksperimente : tez. dokl. Vsesojuz. konferencii. [Use of biophysical methods in a genetic selection experiment: rep. report All-Union. Conference], 1977, pp. 59. (in Russian)

11. Maksimenko A. P., Gersh V. A., Gvozdyk E. N. Ispol'zovaniye lazera v lesnom khozyaystve [The use of laser in forestry] Lazernye tehnologii v sel'skom hozjajstve. [Laser technologies in agriculture] Moscow, 2008, pp. 124-129. (in Russian)

12. Plokhikh V. B., Matsutsina L. B. Lazer v selektsii i semenovodstve [Laser in breeding and seed production] Saharnaja svekla [Sugar beet], 1985, pp. 29-31. (in Russian)

\section{Сведения об̆ авторах}

Подвигина Ольга Анатольевна - ведущий научный сотрудник ФГБНУ «Всероссийский научноисследовательский институт сахарной свеклы и сахара имени А.Л. Мазлумова», доктор сельскохозяйственных наук, п. ВНИИСС, Российская Федерация; e-mail: vniiss@mail.ru.

Бартенев Игорь Иванович - заведующий отделом семеноводства и семеноведения сахарной свеклы с элементами механизации ФГБНУ «Всероссийский научно-исследовательский институт сахарной свеклы и сахара имени А.Л. Мазлумова», кандидат технических наук, п. ВНИИСС, Российская Федерация; е-mail: vniiss@mail.ru.

Сащенко Сергей Вячеславович - ООО «Бетагран Рамонь», кандидат сельскохозяйственных наук, п. ВНИИСС, Российская Федерация; e-mail: vniiss@mail.ru.

\section{Information about authors}

Podvigina Olga Anatolievna - Leading Researcher, FSBSI «All-Russian Research Institute of Sugar Beet and Sugar named after A.L. Mazlumov», DSc (Agriculture), village VNIISS, Russian Federation; e-mail: vniiss@mail.ru.

Bartenev Igor Ivanovich - Head of the Department of Seed Growing and Seed Research of Sugar Beets with Elements of Mechanization, FSBSI «All-Russian Research Institute of Sugar Beet and Sugar named after A.L. Mazlumov», PhD (Engineering), village VNIISS, Russian Federation; e-mail: vniiss@mail.ru.

Sashchenko Sergey Vyacheslavovich - LLC «Betagran Ramon», PhD (Agriculture), village VNIISS, Russian Federation; e-mail: vniiss@mail.ru. 